\title{
The Impact of Social Media on Improving the Services of the Department of Lands and Survey in Jordan
}

\author{
Dr. Talal Medhan Flyh Al Mhareb ${ }^{1}$ \\ ${ }^{1}$ University of Jordan, Jordan \\ Correspondence: Dr. Talal Medhan Flyh Al Mhareb, University of Jordan, Jordan. E-mail: \\ m.alzboon@yahoo.com
}

Received: September 12, 2019

Accepted: September 26, 2019

Online Published: September 27, 2019

doi:10.5539/mas.v13n10p148

URL: https://doi.org/10.5539/mas.v13n10p148

\begin{abstract}
The present study aimed to identify the impact of social media on improving the services of the Department of Lands and Survey in Jordan. To meet the study's goals, a forty-item questionnaire was developed. This questionnaire covers four areas. The questionnaire forms were distributed to 737 service recipients of the Department of Lands and Survey in Jordan. It was found that social media has a significant impact on improving the services of the Department of Lands and Survey in Jordan. It was found that Facebook, WhatsApp, YouTube, and Twitter have the greatest impact respectively on improving the services of the Department of Lands and Survey in Jordan. It was found that there isn't any statistically significant difference -at the statistical significance level of $(a=0.05)$ - between the respondents' attitudes in this regard which can be attributed to (gender or academic qualification). It was found that there is a statistically significant difference -at the statistical significance level of $(\mathrm{a}=0.05)$ - between the respondents' attitudes in this regard which can be attributed to (nationality). The latter difference is for the favor of Jordanians. Based on the afore mentioned results, the researcher recommends:

1. Distributing pamphlets to the service recipients of the Department of Lands and Survey in Jordan. Such pamphlets must encourage them to follow the official page of the latter department on Twitter

2. Responding faster to the inquiries of the service recipients of the Department of Lands and Survey that are sent through WhatsApp.
\end{abstract}

Keywords: social media, the department of lands and survey

\section{Introduction}

ICTs have a great impact on the service sector. For instance, they are employed for meeting the customers' needs within a short time. That is highly needed by the customers who suffer from time pressure. The significance of social media in the service sector has been increasing. The concept of social media has several dimensions. These dimensions affect the way in which the customer assess the product and the organization. Social media can be used for increasing the profits of the organization. It can be used for improving the organizational competiveness. That's needed in the light of having many organizations providing the same services. The use of social media can reduce the extent of need for launching an intensive promotional campaign. It shall hinder other organizations from entering the concerned market. It shall enable the organization to enter new markets. It shall ensure the survival of the organization. It shall improve the mental image that customers have about the concerned organization. It shall enable the organization to respond fast and efficiently to the customers' inquiries. It shall enable the organization to provide customers with services fast and efficiently. In this regard, it should be noted that the Department of Lands and Survey in Jordan is in need for doing that. That's because there is a great number of service recipients of the Department of Lands and Survey in Jordan. For instance, the building of the latter department is overcrowded with many service recipients in a daily manner. Therefore, the latter department must search for methods that make its building less crowded with service recipients. That can be done through finding methods for replying to the service recipients' inquiries without forcing them to visit the department itself.

ICTs can connect peoples with each other. That applies regardless of the orientations of each people. ICTs enable people to overcome the political and geographical limitations. They enable people to avoid isolation. 
Today, the world has been experiencing major transformations in the field of ICTs. These transformations affect the political and economic relations between countries. They also affect the thinking patterns of people. In this regard, it should be noted that social media plays a significant role in various situations. It plays a significant role in promoting awareness and changing people's thoughts. It can be used for learning languages and translating texts from Arabic language into other languages. It facilitates the communication process between young people. It bridges the cultural gaps between people. It enables people to share material and interact with it. It enables people to keep in touch with others with overcoming the spatial limitations. The number of social media users has been increasing. Thus, the impacts of social media have been increasing too. Social media has been increasingly making transformations. Due to such increasing number of social media users, social media has being significantly affecting the public opinion about social, political, and economic issues. For instance, social media has been highlighting news about events in a manner that outperforms TV channels, radio channels and other media outlets. The electronic media plays a significant role in drafting and spreading news. Social media is considered one of the electronic media outlet. It provides people with much freedom in selecting topics to talk about, and editing texts. It facilitates the process of transmitting news and reduces the cost associated with such transmission (Al-Madani, 2015).

\section{Statement of the Problem}

The problem of this study is represented in the following question:

What's the impact of social media on improving the services of the Department of Lands and Survey in Jordan from the perspective of the service recipients of this department?

The following sub-questions are derived from the main question:

Q.1. What's the impact of Facebook on improving the services of the Department of Lands and Survey in Jordan from the perspective of the service recipients of this department?

Q.2. What's the impact of YouTube on improving the services of the Department of Lands and Survey in Jordan from the perspective of the service recipients of this department?

Q.3. What's the impact of WhatsApp on improving the services of the Department of Lands and Survey in Jordan from the perspective of the service recipients of this department?

Q.4. What's the impact of Twitter on improving the services of the Department of Lands and Survey in Jordan from the perspective of the service recipients of this department?

Q.5 Is there any statistically significant difference -at the statistical significance level of $(a=0.05)$ - between the impacts of the social media on improving the services of the Department which can be attributed to (nationality, gender or academic qualification)?

\section{The Study's Objectives}

The present study aimed to:

1- Identify the impact of social media on improving the services of the Department of Lands and Survey in Jordan

2- Identify the impact of Facebook on improving the services of the Department of Lands and Survey in Jordan

3- Identify the impact of YouTube on improving the services of the Department of Lands and Survey in Jordan

4- Identify the impact of WhatsApp on improving the services of the Department of Lands and Survey in Jordan

5- Identify the impact of Twitter on improving the services of the Department of Lands and Survey in Jordan

6- Identify whether there is any statistically significant difference -at the statistical significance level of $(\mathrm{a}=0.05)$ - between the respondents' attitudes in this regard which can be attributed to (nationality, gender or academic qualification)

\section{The Study's Significance}

The present study is significant because:

1- It sheds a light on the impact of social media on improving the services of the Department of Lands and Survey in Jordan 
2- It sheds a light on the nature of social media. It provides an analysis for the issues related to social media.

3- This is the first study that sheds a light on the impact of social media on improving the services of the Department of Lands and Survey in Jordan. That is as far as the researchers know. Thus, the present study shall fill a gap in the relevant literature.

4- It provides the Department of Lands and Survey with knowledge about the way of using social media and delivering news through it.

5- It shall benefit researchers through serving as a reference that can enrich their studies. It shall encourage researchers to search for more information about the issues related to this topic.

\section{The Study's Limits}

- Spatial limits: The present study targets the Lands and Survey in Jordan

- Temporal limits: The present study was conducted during 2019

- Human limits: The present study targets the service recipients of the Department of Lands and Survey in Jordan

\section{The Study's Terms}

Social media: They refer to platforms that enable their users to create their owns profiles, communicate with others, upload posts, and post photos (Reita, 2012)

The Department of Lands and Survey: It's a public department located in the Hashemite Kingdom of Jordan. People visit this department to do land-related paper works, such as: the paper works related to sale transaction, parceling out property, transference of ownership, land scheme, the bond of registration of land ownership, insurance, seizure, and extraction of statement of property report and etc...

\section{Previous Studies}

After reviewing the relevant studies, it was found that there isn't any study that is directly connected to the study's subject. It was found that there isn't any study that targets the same population in this regard. In other words, this is the first study that sheds a light on this subject. Therefore, the researcher reviewed the studies that are indirectly related to the study's subject. However, such studies target a different population. These studies are identified below:

Qasem and Dayoob (2018) aimed to identify the relationship between the use of social media (Facebook) by the customers of Syrian Telecommunication companies for communication goals and the capacity of these companies to influence their customers during each phase of the purchasing process phases. The targeted phases include: the need generation phase, the phase of searching for alternatives, the phases of assessing alternatives, the phase of making the purchasing decision, and the post-purchasing phase. To meet the study's goals, the main hypothesis and the sub-hypotheses were developed. A questionnaire was used for collecting data. Several results were concluded. For instance, it was found that there is a positive relationship between the use of Facebook by the customers of Syrian Telecommunication companies for promotional goals from one hand and all the purchasing phases from another hand.

Florez (2018) aimed to identify the impact of social media on the purchasing decisions of university students. He aimed to do that through adapting the model of Okazaki (2012) with the study's goals. The latter researcher aimed to identify the factors that stimulate customers to use social media for carrying out the purchasing process. A quantitative approach was adopted and a questionnaire was used for data collection. The questionnaire was developed based on the latter model. The questionnaire forms were distributed to 224 university students who were selected from the engineering department at National Colombia University in Medellin. It was found that the use of social media for searching and purchasing products is highly accepted by university students. It was found that the word of mouth has a significant impact on the process of making the purchasing decision. It was found that the use of social media for advertising-related goals shall add a competitive advantage to organizations. The cost of using social media for advertising-related goals is low. The social media pages can be easily accessed by customers.

Al-Nsour et al (2016) aimed to identify the impact of using social media for advertising on the purchasing intention of customers in Jordan. The latter use is represented in two dimensions: the company-generated content and the user generated content. The purposive sampling method was used to select a sample. The sample consists from several people who use social media to buy products. The analytical descriptive approach was adopted. 
Several results were concluded. For instance, it was found that social media for advertising has a significant impact on the purchasing intention of customers. It was found that the company-generated content and the user generated content have a significant impact on the purchasing intention of customers. Regarding the extent of use, Facebook was ranked first, YouTube was ranked second, Twitter and Instagram are ranked third and LinkedIn is ranked last.

Mustafa (2016) aimed to shed a light on social media. His study promoted awareness among the management of telecommunication companies about the significance of exerting effort to make sure that customers have positive mental image about them. The latter researcher found that social media has a positive impact on improving the mental image that customers have about the telecommunication companies. To meet the study's goals, a questionnaire was used. A random sample was selected from the study's population. It consists from 260 employees. After retrieving the questionnaire forms, the data was analyzed statistically. Several results were concluded. For instance, it was found that social media plays a significant role in enhancing the mental image that customers have about the telecommunication companies. Such image can be improved through raising the customer satisfaction level. Companies have been assigning teams for running social media pages. The members of such teams are specialized in marketing. Each member is responsible for performing a specific task. All the members of the team work together and collaborate to meet the interests of the company they work for. Such teams are usually responsible for meeting specific goals, serving customers, raising the sales volume, creating goodwill and developing marketing strategies.

Al-Kurashi and Al-Kelani (2015) aimed to identify the impact of social media on the process of making the purchasing decision by consumers. They aimed to identify the impact of social media on each phase of the phases of the purchasing decision making process. The population consists from all the consumers who would like to use social media for buying products in Amman. A questionnaire was used for collecting data. The sample consists from 430 consumers. It was found that social media has a significant impact on the process of making the purchasing decision by consumers. It was found that social media affects the extent of customers' realization for the capacity of the advertised products to meet their needs. It was found that social media helps the consumers in looking for alternative products to meet their needs. It was found that social media enables consumers to identify the best alternative products among the available alternative products. It was found that social media helps consumers in performing the actual purchasing process. It was found that social media helps consumers in assessing the product after making the actual purchasing process.

Al-Mansour (2012) aimed to conduct a comparison between social media and electronic websites. To meet the study's goals, an analytical descriptive approach was adopted. A forty-item questionnaire was developed. The questionnaire sheds a light on two areas. A random sample was selected to meet the study's goals. It consists from 350 individuals. The questionnaire forms were distributed to those individuals. It was found that browsers of websites can't give up the use of social media. That's because social media provides full and detailed information about the latest events. It's because social media provide useful information about various fields. It's because social media enables people to talk with their family members, friends and colleagues at workplace or academic institution. It's because social media enables people to exchange files, photos and videos with others. It's because social media enables people to express their opinions and comment on others' opinions. It's because social media enables people to reply to others' comments and create virtual friendship with others.

Vansoon (2010) aimed to identify the impact of social media on advertising the services provided by organizations. In order to meet the study's goals, an analytical descriptive approach was adopted. A questionnaire was used for collecting data. A random sample was selected. It consists from 1600 young British individuals. Several results were concluded. For instance, it was found that the use of social media has a significant impact on advertising the services provided by organizations. It was found that social media has changed the lives of many people. To illustrate more, due to the invention of social media, many people today spend much time on the web. Some people even spend time on the web more than the time they spend with their real friends and family members. It was found that $50 \%$ of the internet users in Britain are social media users. It was found that $27 \%$ of the internet users in France are social media users. It was found that $33 \%$ of the internet users in japan are social media users. It was found that $40 \%$ of the internet users in the United States are social media users.

\section{Comments on the Aforementioned Studies and the Difference between Them and the Present Study}

Through reviewing the aforementioned studies, it can be noticed that all of them address social media-related issues. The temporal limits of these studies fall within the range of (2010-2018). That means that social 
media-related issues are considered important issues during the contemporary age. These issues have been receiving the attention of many researchers.

Most of the aforementioned studies adopt a descriptive approach. That indicates that this approach is suitable for addressing social media-related issues. It can be noticed that the size of the samples of the aforementioned studies is consistent with the size of their population. Some of the aforementioned studies are conducted in Arabic language, whereas the others are conducted in English language.

The aforementioned studies enabled the researcher of the present study to develop the research structure and select an approach. They enabled the researcher to determine the sample size, develop the study's instrument, and choose the suitable statistical methods. They enabled the researcher to draft the study's questions. The researcher hopes that the present study shall enrich the relevant literature that targets social media in countries in general and in the Arab World in particular. The difference between the aforementioned studies and the present study is represented in the population. For instance, the population of the present study is represented in all the service recipients of the Department of Lands and Survey in Jordan. The present study is the first study that sheds a light on this topic.

\subsection{The Study's Approach}

A descriptive approach was adopted. That's because it is appropriate for this type of studies. This approach is usually adopted in order to interpret a specific phenomenon or a problem. That is done through identifying the dimensions of the concerned phenomenon or the concerned problem and the circumstances surrounding it. That is done through identifying the relationship between such dimensions. Through adopting the descriptive approach, a detailed complete description shall be provided for the concerned phenomenon or the concerned problem. Such a description is provided based on facts.

\subsection{Population}

The population of the present study is represented in all the service recipients of the Department of Lands and Survey in Jordan. The size of the population is too big. Thus, it's difficult to select all the members of the population as a sample

\subsection{Sample}

A random sample was selected. The questionnaire forms were distributed to 820 individuals who are service recipients of the Department of Lands and Survey in Jordan. 750 questionnaire forms were retrieved. However, 737 questionnaire forms were considered valid for statistical analysis. Table 1 Blow presents the distribution of the respondents in accordance with the study's variables

Table 1. The distribution of the respondents in accordance with the study's variables

\begin{tabular}{cccc}
\hline Variable & Category & Frequency & Percentage \\
\hline Gender & Male & 575 & 78.0 \\
& Female & 162 & 22.0 \\
Nationality & Total & $\mathbf{7 3 7}$ & $\mathbf{1 0 0 . 0}$ \\
& Jordanian & 641 & 87.0 \\
& Non-Jordanian & 96 & 13.0 \\
Academic qualifications & Total & $\mathbf{7 3 7}$ & $\mathbf{1 0 0 . 0}$ \\
& Secondary school certificate & 228 & 30.9 \\
& Diploma degree & 105 & 14.2 \\
The type of paperwork that & BA degree & 281 & 38.1 \\
made the respondent visit & Higher studies & 123 & 16.7 \\
the department & Total & $\mathbf{7 3 7}$ & $\mathbf{1 0 0 . 0}$ \\
& Sale transaction & $\mathbf{1 6 1}$ & \\
& Parcel out property & $\mathbf{9 5}$ & \\
& Transference of ownership & $\mathbf{1 1 8}$ & \\
& Land scheme and the bond of & $\mathbf{2 1 2}$ & \\
& registration of land ownership & $\mathbf{8 1}$ & \\
& Insurance & $\mathbf{7 3}$ & \\
& Seizure & $\mathbf{5 2}$ & \\
& Extraction of statement of property & $\mathbf{7 3 7}$ & \\
\hline & Total &
\end{tabular}




\subsection{The Study's Instrument and Validity}

The researcher developed a questionnaire to identify the impact of social media on improving the services of the Department of Lands and Survey in Jordan. The questionnaire was passed to several experts who are specialized in relevant fields. Some of the experts recommended adding additional items to the questionnaire. Other experts recommended redrafting some items. The final version of the questionnaire consists from 40 statements. It sheds a light on four areas. It consists from two parts, which are:

- $\quad$ The first part: It collects demographic data (i.e. nationality, gender or academic qualification).

- The second part: It includes 40 statement that covers four areas. The first area is Facebook (19 statements).

The second area is YouTube (6 statements). The third area is WhatsApp (10 statements). The fourth area is

Twitter (5 statements).

The reliability of the instrument:

The values of Cronbach Alpha coefficient were calculated to measure the reliability of the instrument. They are presented below:

Table 2. The values of Cronbach Alpha coefficient

\begin{tabular}{ccc}
\hline No. & Area & $\begin{array}{c}\text { Value of Cronbach Alpha } \\
\text { coefficient }\end{array}$ \\
\hline 1 & $\begin{array}{c}\text { The impact of Facebook on improving the services of } \\
\text { the Department of Lands and Survey }\end{array}$ & .82 \\
2 & $\begin{array}{c}\text { The impact of YouTube on improving the services of } \\
\text { the Department of Lands and Survey }\end{array}$ & .79 \\
3 & $\begin{array}{c}\text { The impact of WhatsApp on improving the services of } \\
\text { the Department of Lands and Survey }\end{array}$ & .80 \\
4 & $\begin{array}{c}\text { The impact of Twitter on improving the services of the } \\
\text { Department of Lands and Survey }\end{array}$ & .80 \\
\hline
\end{tabular}

The values in table 2 are within the range of (.82-.79). These values are accepted and enable the researcher to meet the study's goals.

The Study's Results:

This part presents the study's results. The results were reached through using SPSS program. The means are classified based on the following criteria (E'layan, 2012)

4.21 or more: very high

4.20 - 3.41: high

3.40 - 2.61: moderate

$2.60-1.81$ : low

Less than 1.81: very low

\section{Results}

The main question: What's the impact of social media on improving the services of the Department of Lands and Survey in Jordan?

To answer the main question, the researcher provided answers for the sub-questions first

Q.1. What's the impact of Facebook on improving the services of the Department of Lands and Survey in Jordan from the perspective of the service recipients of this department?

To answer this question, means and standard deviations are calculated and presented in table (3) below 
Table 3. The means and standard deviations of the impact of Facebook on improving the services of the Department of Lands and Survey in Jordan

\begin{tabular}{|c|c|c|c|c|}
\hline No. & Statement & Mean & Std. & Level \\
\hline .1 & $\begin{array}{l}\text { The creation of FB page reduced the amount of effort I exert } \\
\text { to obtain information }\end{array}$ & 4.72 & 0.44 & Very high \\
\hline .2 & $\begin{array}{l}\text { The Facebook page of the department publishes stories about } \\
\text { the department's services in a detailed manner }\end{array}$ & 4.66 & 0.47 & Very high \\
\hline .3 & $\begin{array}{c}\text { The Facebook page of the Department of Lands and Survey is } \\
\text { highly reliable }\end{array}$ & 4.61 & 0.48 & Very high \\
\hline .4 & $\begin{array}{l}\text { The Facebook page of the Department of Lands and Survey } \\
\text { identifies the vision and mission of the latter department }\end{array}$ & 4.61 & 0.56 & Very high \\
\hline .5 & $\begin{array}{l}\text { The Facebook page of the Department of Lands and Survey } \\
\text { seeks promoting a good image about the latter department }\end{array}$ & 4.48 & 0.56 & Very high \\
\hline .6 & $\begin{array}{l}\text { The administrators of the Facebook page of the Department of } \\
\text { Lands and Survey provides attention to what I post }\end{array}$ & 4.47 & 0.51 & Very high \\
\hline .7 & $\begin{array}{c}\text { The administrators of the Facebook page of the Department of } \\
\text { Lands and Survey reply to all the inquiries I post in a } \\
\text { professional manner }\end{array}$ & 4.44 & 0.49 & Very high \\
\hline .8 & $\begin{array}{l}\text { I am highly satisfied with the role of the FB page in } \\
\text { promoting awareness about the services of the department }\end{array}$ & 4.42 & 0.56 & Very high \\
\hline .9 & $\begin{array}{l}\text { The creation of a FB page reduced the costs incurred to } \\
\text { receive services }\end{array}$ & 4.39 & 0.55 & Very high \\
\hline .10 & $\begin{array}{l}\text { The administrators of the Facebook page of the Department of } \\
\text { Lands and Survey deal tactfully and professionally with } \\
\text { service recipients }\end{array}$ & 4.38 & 0.55 & Very high \\
\hline .11 & $\begin{array}{l}\text { The official page provides information about the work } \\
\text { measures in a detailed manner }\end{array}$ & 4.37 & 0.63 & Very high \\
\hline .12 & $\begin{array}{l}\text { My notes and suggestions that I inbox to the FB page of the } \\
\text { department are taken into consideration }\end{array}$ & 4.33 & 0.67 & Very high \\
\hline .13 & $\begin{array}{l}\text { I think that I have gained more knowledge about the } \\
\text { department through following up the FB page }\end{array}$ & 4.27 & 0.51 & Very high \\
\hline .14 & $\begin{array}{c}\text { The FB page has become the mean that I use for doing my } \\
\text { paper works }\end{array}$ & 4.24 & 0.58 & Very high \\
\hline .15 & $\begin{array}{c}\text { The administrators of the Facebook page reply to all my } \\
\text { inquiries professionally }\end{array}$ & 4.20 & 0.55 & High \\
\hline .16 & People interact with my opinions that I post on the FB page & 4.13 & 0.59 & High \\
\hline .17 & $\begin{array}{l}\text { The performance of the administrators of the Facebook page } \\
\text { has been rising in terms of the way they draft news }\end{array}$ & 4.07 & 0.73 & High \\
\hline .18 & $\begin{array}{c}\text { The FB page is considered the best mean for communicating } \\
\text { with the services recipient }\end{array}$ & 3.97 & 0.67 & High \\
\hline \multirow[t]{2}{*}{.19} & $\begin{array}{l}\text { There is a great attention provided to my comments on the FB } \\
\text { page }\end{array}$ & 3.95 & 0.58 & High \\
\hline & Total & 4.3540 & 0.28 & Very high \\
\hline
\end{tabular}

Based on table 3, it was found that Facebook has a very strong impact on improving the services of the Department of Lands and Survey in Jordan. The means are either moderate or low. They are within the range of 4.72-3.95. The overall mean is very high. It is 4.35 . That means that Facebook has a very strong impact on improving the services of the Department of Lands and Survey in Jordan.

It was found that the creation of FB page reduced the amount of effort exerted by service recipients to obtain information. It was found that the Facebook page of the department publishes stories about the department's services in a detailed manner. The researcher attributes these results to the fact that FB is the most widely used social media website in Jordan. He attributes these results to the fact that the service recipients use FB in a regular manner. 
Q.2. What's the impact of YouTube on improving the services of the Department of Lands and Survey in Jordan from the perspective of the service recipients of this department?

To answer this question, means and standard deviations are calculated and presented in table (4) below

Table 4. The means and standard deviations of the impact of YouTube on improving the services of the Department of Lands and Survey in Jordan

\begin{tabular}{|c|c|c|c|c|}
\hline No. & Statement & Mean & Std. & Level \\
\hline .1 & $\begin{array}{l}\text { The Department of Lands and Survey upload illustrative } \\
\text { videos that illustrate the way of obtaining electronic } \\
\text { services }\end{array}$ & 3.67 & 0.96 & High \\
\hline .2 & $\begin{array}{c}\text { The videos that provides information about the measures } \\
\text { of doing paper works enables service recipients to } \\
\text { understand these measures }\end{array}$ & 3.37 & 0.86 & Moderate \\
\hline .3 & $\begin{array}{l}\text { The videos posted by the Department of Lands and } \\
\text { Survey provides me with the latest updates }\end{array}$ & 3.36 & 0.93 & Moderate \\
\hline .4 & $\begin{array}{l}\text { YouTube is considered the best method for obtaining } \\
\text { knowledge about measures }\end{array}$ & 3.35 & 0.72 & Moderate \\
\hline .5 & $\begin{array}{l}\text { The Department of Lands and Survey upload videos that } \\
\text { serve as a reply to the inquiries of service recipients }\end{array}$ & 2.96 & 0.82 & Moderate \\
\hline .6 & $\begin{array}{l}\text { The videos posted by the Department of Lands and } \\
\text { Survey help me in solving my problems }\end{array}$ & 2.84 & 0.78 & Moderate \\
\hline & Total & 3.2580 & 0.31 & Moderate \\
\hline
\end{tabular}

Based on table 4, it was found that YouTube has a moderate impact on improving the services of the Department of Lands and Survey in Jordan. The means are either moderate or high. They are within the range of 3.67-2.84. The overall mean is moderate. It is 3.2580 . That means that the service recipients provide moderate attention to watching the YouTube videos uploaded by the aforementioned department. The researcher attributes this results to the fact that the service recipients of this department do not have much interest in watching the illustrative videos that are uploaded by the department. However, it should be noted that the latter department provides much attention to uploading that reply transparently to the inquiries of the service recipients. It should be also noted that the videos uploaded by the department enables the service recipients to solve their problems.

Q.3. What's the impact of WhatsApp on improving the services of the Department of Lands and Survey in Jordan from the perspective of the service recipients of this department?

To answer this question, means and standard deviations are calculated and presented in table (5) below 
Table 5. The means and standard deviations of the impact of WhatsApp on improving the services of the Department of Lands and Survey in Jordan

\begin{tabular}{|c|c|c|c|c|}
\hline No. & Statement & Mean & Std. & Level \\
\hline .1 & $\begin{array}{l}\text { The Department of Lands and Survey seeks fighting the } \\
\text { false news in a transparent manner through using } \\
\text { WhatsApp }\end{array}$ & 4.02 & 0.72 & High \\
\hline .2 & WhatsApp enabled me to submit a complaint & 4.00 & 0.72 & High \\
\hline .3 & $\begin{array}{l}\text { WhatsApp provides me with updated information that is } \\
\text { important for doing work tasks }\end{array}$ & 3.92 & 0.62 & High \\
\hline .4 & $\begin{array}{c}\text { WhatsApp can be used for doing all types of paper } \\
\text { works effectively }\end{array}$ & 3.85 & 0.75 & High \\
\hline .5 & $\begin{array}{l}\text { I communicate effectively with the employees who work } \\
\text { at the Department of Lands and Survey through using } \\
\text { WhatsApp. That enables me to do tasks }\end{array}$ & 3.84 & 0.74 & High \\
\hline .6 & $\begin{array}{l}\text { The WhatsApp services provided by the Department of } \\
\text { Lands and Survey are very important for me }\end{array}$ & 3.74 & 0.77 & High \\
\hline .7 & $\begin{array}{c}\text { The use of WhatsApp enabled me to submit more } \\
\text { suggestions }\end{array}$ & 3.72 & 0.83 & High \\
\hline .8 & $\begin{array}{l}\text { The use of WhatsApp enabled me to communicate } \\
\text { with the employees who work at the Department of } \\
\text { Lands and Survey }\end{array}$ & 3.67 & 0.69 & High \\
\hline .9 & $\begin{array}{l}\text { The Department of Lands and Survey delivers } \\
\text { WhatsApp awareness-raising messages }\end{array}$ & 3.66 & 0.78 & High \\
\hline .10 & $\begin{array}{l}\text { The complaints sent to the department through } \\
\text { WhatsApp are handled professionally }\end{array}$ & 3.55 & 0.73 & High \\
\hline & Total & 3.7973 & 0.19 & High \\
\hline
\end{tabular}

Based on table 5, it was found that WhatsApp has a strong impact on improving the services of the Department of Lands and Survey in Jordan. The means are either moderate or low. They are within the range of 4.02-3.55. The overall mean is high. It is 3.7973. It was found that the Department of Lands and Survey seeks fighting the false news in a transparent manner through using WhatsApp. It was found that WhatsApp enables service recipients to submit complaints. It was found that WhatsApp provide the service recipients of the Department of Lands and Survey with updated information that is important for doing work tasks. It was found that service recipients find the use of WhatsApp easy and keep following up the news delivered through it.

Q.4. What's the impact of Twitter on improving the services of the Department of Lands and Survey in Jordan from the perspective of the service recipients of this department?

To answer this question, means and standard deviations are calculated and presented in table (6) below

Table 6. The means and standard deviations of the impact of Twitter on improving the services of the Department of Lands and Survey in Jordan

\begin{tabular}{|c|c|c|c|c|}
\hline No. & Statement & Mean & Std. & Level \\
\hline 1 & $\begin{array}{l}\text { The awareness-raising tweets on the department's } \\
\text { Twitter page benefitted me }\end{array}$ & 3.50 & 0.58 & High \\
\hline 2 & $\begin{array}{c}\text { The illustrative videos on the department's Twitter page } \\
\text { reduced the costs }\end{array}$ & 2.50 & 1.12 & Low \\
\hline 3 & $\begin{array}{c}\text { The department's Twitter page is an effective mean for } \\
\text { fighting against false news }\end{array}$ & 2.47 & 0.85 & Low \\
\hline 4 & $\begin{array}{l}\text { The department's Twitter page post tweets about the } \\
\text { national and religious events }\end{array}$ & 2.37 & 0.81 & Low \\
\hline 5 & $\begin{array}{l}\text { The department's Twitter page provides me with the } \\
\text { latest updated information in an accurate manner }\end{array}$ & 2.25 & 0.84 & Low \\
\hline & Total & 2.60 & 0.28 & Low \\
\hline
\end{tabular}


Based on table 6, it was found that Twitter has a weak impact on improving the services of the Department of Lands and Survey in Jordan. The means are either moderate or low. They are within the range of 3.50-2.55. The overall mean is low. It is 2.60 . The researcher attributes the latter results to the fact that Twitter isn't widely used in Jordan. Thus, the Department of Lands and Survey provides attention to its FB page that is more than the attention it provides to its Twitter page and WhatsApp. Therefore, the department isn't highly concerned in delivering information through its Twitter page.

The main question: What's the impact of social media on improving the services of the Department of Lands and Survey in Jordan?

To answer this question, means and standard deviations are calculated and presented in table (7) below

Table 7. The means and standard deviations of the impact social media on improving the services of the Department of Lands and Survey in Jordan

\begin{tabular}{ccccc}
\hline No. & Statement & Mean & Std. & Level \\
\hline 1 & $\begin{array}{c}\text { The impact of Facebook on improving the services of } \\
\text { the Department of Lands and Survey in Jordan }\end{array}$ & 4.3540 & 0.28185 & Very high \\
2 & $\begin{array}{c}\text { The impact of WhatsApp on improving the services of } \\
\text { the Department of Lands and Survey in Jordan }\end{array}$ & 3.7973 & 0.19662 & High \\
3 & $\begin{array}{c}\text { The impact of YouTube on improving the services of } \\
\text { the Department of Lands and Survey in Jordan }\end{array}$ & 3.2580 & 0.31172 & Moderate \\
4 & $\begin{array}{c}\text { The impact of Twitter on improving the services of } \\
\text { the Department of Lands and Survey in Jordan } \\
\text { Total }\end{array}$ & 2.6350 & 0.28802 & Moderate \\
& 3.5111 & 0.15752 & High \\
\hline
\end{tabular}

Based on table 7, it was found that social media has a strong impact on improving the services of the Department of Lands and Survey in Jordan. The means are within the range of 4.35-2.63. The overall mean is 3.5111. It is high. It was found that Facebook is ranked first in terms of its impact on improving the services of the Department of Lands and Survey in Jordan. It was found that WhatsApp is ranked second and YouTube is ranked third in this regard. It was found that Twitter is ranked fourth in this regard. The researcher attributes these results to the fact that social media platforms are highly used by the service recipients of the Department of Lands and Survey in Jordan. Therefore, the latter department publishes information, replies to inquiries, upload videos and post illustrative online pamphlets through using social media. It carries out these tasks in order to improve its services and enable the service recipients to benefit optimally from the provided optimally.

Q.5 Is there any statistically significant difference - at the statistical significance level of $(a=0.05)$ - between the impacts of the social media on improving the services of the Department which can be attributed to gender?

To identify whether the differences are statistically significant or not, the t-test for two independent samples was conducted. The results of the latter test are presented in table (8) below

Table 8 . The results of the t-test for two independent samples for identifying the statistical significance between the impacts of the social media on improving the services of the Department which can be attributed to gender

\begin{tabular}{ccccccc}
\hline Area & Category & Frequency & Mean & Std. & T value & Sig. \\
\hline Facebook & Male & 575 & 4.3486 & 0.28862 & $0.987-$ & 0.32 \\
& Female & 162 & 4.3733 & 0.25629 & & \\
YouTube & Male & 575 & 3.2623 & 0.30928 & 0.704 & 0.48 \\
& Female & 162 & 3.2428 & 0.32072 & & \\
WhatsApp & Male & 575 & 3.8077 & 0.19248 & 2.708 & 0.007 \\
& Female & 162 & 3.7605 & 0.20713 & & \\
Twitter & Male & 575 & 2.6362 & 0.29052 & \multirow{2}{*}{0.207} & 0.83 \\
& Female & 162 & 2.6309 & 0.27981 & & \multirow{2}{*}{ Total } \\
& Male & 575 & 3.5137 & 0.15752 & 0.843 & 0.40 \\
& Female & 162 & 3.5019 & 0.15769 & & \\
\hline
\end{tabular}

*The statistical significance level is $(\mathrm{a}=0.05)$ 
Based on the table (8), there isn't any statistically significant difference -at the statistical significance level of $(\mathrm{a}=0.05)$ - between the impacts of the social media on improving the services of the Department which can be attributed to gender. That's because the significance value is 0.40 which is greater than 0.05 . Thus, the null hypothesis is rejected. That means that there isn't any statistically significant difference between the respondents' attitudes in this regard which can be attributed to their gender. The researcher attributes this result to the fact that female and males service recipients deal in a similar manner with social media. He also attributes this result to the fact that the posts of the department on social media address female and male service recipients. Thus, female and male respondents have similar attitudes.

Q.6 Is there any statistically significant difference -at the statistical significance level of $(a=0.05)$ - between the impacts of the social media on improving the services of the Department which can be attributed to nationality?

To identify whether the differences are statistically significant or not, the t-test for two independent samples was conducted. The results of the latter test are presented in table (9) below

Table 9. The results of the t-test for two independent samples for identifying the statistical significance between the impacts of the social media on improving the services of the Department which can be attributed to nationality

\begin{tabular}{|c|c|c|c|c|c|c|}
\hline Area & Category & Frequency & Mean & Std. & T value & Sig. \\
\hline \multirow[t]{2}{*}{ Facebook } & Jordanian & 641 & 4.3487 & 0.28725 & $1.315-$ & 0.18 \\
\hline & $\begin{array}{c}\text { Non- } \\
\text { Jordanian }\end{array}$ & 96 & 4.3893 & 0.24106 & & \\
\hline \multirow[t]{2}{*}{ YouTube } & Jordanian & 641 & 3.2683 & .31198 & 2.325 & 0.02 \\
\hline & $\begin{array}{c}\text { Non- } \\
\text { Jordanian }\end{array}$ & 96 & 3.1892 & 0.30264 & & \\
\hline \multirow[t]{2}{*}{ WhatsApp } & Jordanian & 641 & 3.8064 & 0.19196 & 3.272 & 0.00 \\
\hline & $\begin{array}{c}\text { Non- } \\
\text { Jordanian }\end{array}$ & 96 & 3.7365 & 0.21673 & & \\
\hline \multirow[t]{2}{*}{ Twitter } & Jordanian & 641 & 2.6427 & 0.29280 & & \\
\hline & $\begin{array}{c}\text { Non- } \\
\text { Jordanian }\end{array}$ & 96 & 2.5833 & 0.24907 & 1.888 & 0.05 \\
\hline \multirow[t]{2}{*}{ Total } & Jordanian & 641 & 3.5165 & 0.15745 & 2.443 & 0.01 \\
\hline & $\begin{array}{c}\text { Non- } \\
\text { Jordanian }\end{array}$ & 96 & 3.4746 & 0.15388 & & \\
\hline
\end{tabular}

*The statistical significance level is $(\mathrm{a}=0.05)$

Based on the table (8), there are statistically significant differences -at the statistical significance level of $(\mathrm{a}=0.05)$ - between the impacts of the social media on improving the services of the Department which can be attributed to nationality. That's because the significance value is less than the statistical significance level. Thus, there are statistically significant differences between the respondents' attitudes which can be attributed to nationality. The latter differences are for the favor of the respondents holding Jordanian nationality. That's because the mean of the latter respondents is higher than the mean of the respondents who do not hold Jordanian nationality. The researcher attributes this result to the fact that Jordanian service recipients have more interest than non-Jordanian service recipients in this issue. He also attributes this result to the fact that Jordanian service recipients keep themselves updated with the latest news that concerns the department more than the non-Jordanian service recipients

Q.7. Is there any statistically significant difference - at the statistical significance level of $(a=0.05)$ - between the impacts of the social media on improving the services of the Department which can be attributed to academic qualification?

To answer this question, means and standard deviations were calculated and one way analysis of variance (ANOVA) was conducted. Means and standard deviations are presented in table 10. 
Table 10. Means and standard deviations for the impacts of the social media on improving the services of the Department in accordance with academic qualification

\begin{tabular}{|c|c|c|c|c|}
\hline Area & Category & Frequency & Mean & Std. \\
\hline \multirow[t]{5}{*}{ Facebook } & $\begin{array}{l}\text { Secondary school } \\
\text { certificate or less }\end{array}$ & 228 & 4.34 & 0.28 \\
\hline & Diploma & 105 & 4.35 & 0.27 \\
\hline & BA degree & 281 & 4.36 & 0.2 \\
\hline & Graduate studies & 123 & 4.34 & 0.26 \\
\hline & total & 737 & 4.35 & 0.28 \\
\hline \multirow[t]{5}{*}{ YouTube } & $\begin{array}{l}\text { Secondary school } \\
\text { certificate or less }\end{array}$ & 228 & 3.25 & 0.28 \\
\hline & Diploma & 105 & 3.24 & 0.33 \\
\hline & BA degree & 281 & 3.26 & 0.30 \\
\hline & Graduate studies & 123 & 3.25 & 0.03 \\
\hline & total & 737 & 3.25 & 0.31 \\
\hline \multirow[t]{5}{*}{ WhatsApp } & $\begin{array}{l}\text { Secondary school } \\
\text { certificate or less }\end{array}$ & 228 & 3.80 & 0.19 \\
\hline & Diploma & 105 & 3.80 & 0.22 \\
\hline & BA degree & 281 & 3.79 & 0.18 \\
\hline & Graduate studies & 123 & 3.78 & 0.19 \\
\hline & total & 737 & 3.79 & 0.19 \\
\hline \multirow[t]{5}{*}{ Twitter } & $\begin{array}{l}\text { Secondary school } \\
\text { certificate or less }\end{array}$ & 228 & 2.61 & 0.28 \\
\hline & Diploma & 105 & 2.63 & 0.27 \\
\hline & BA degree & 281 & 2.63 & 0.29 \\
\hline & Graduate studies & 123 & 2.67 & 0.29 \\
\hline & total & 737 & 2.63 & 0.28 \\
\hline \multirow[t]{5}{*}{ Total } & $\begin{array}{l}\text { Secondary school } \\
\text { certificate or less }\end{array}$ & 228 & 3.50 & 0.14 \\
\hline & Diploma & 105 & 3.51 & 0.16 \\
\hline & BA degree & 281 & 3.51 & 0.16 \\
\hline & Graduate studies & 123 & 3.51 & 0.15 \\
\hline & total & 737 & 3.51 & 0.15 \\
\hline
\end{tabular}

Based on table 10 , it appears that there are differences between means that can be attributed to the academic qualifications. The highest mean are obtained by the ones holding a BA degree and the least means are obtained by the ones holding secondary school certificate or less. To identify whether these differences are statistically significant or not, one way analysis of variance (ANOVA) was conducted. Table (11) presents the results of the latter analysis 
Table 11. The results of one way analysis of variance (ANOVA) for identifying the statistical significance of the differences that can be attributed to academic qualifications

\begin{tabular}{|c|c|c|c|c|c|c|}
\hline Area & $\begin{array}{l}\text { Source of } \\
\text { variance }\end{array}$ & $\begin{array}{l}\text { Sum of } \\
\text { squares }\end{array}$ & $d f$ & $\begin{array}{l}\text { Mean of } \\
\text { squares }\end{array}$ & $\begin{array}{c}\text { Calculated } f \\
\text { value }\end{array}$ & $P$ \\
\hline \multirow[t]{3}{*}{ Facebook } & $\begin{array}{c}\text { Between } \\
\text { groups }\end{array}$ & 3 & 0.100 & 0.033 & 0.739 & 0.420 \\
\hline & $\begin{array}{l}\text { Within } \\
\text { groups }\end{array}$ & 733 & 58.367 & 0.080 & & \\
\hline & Total & 736 & 58.467 & & & \\
\hline \multirow[t]{3}{*}{ YouTube } & $\begin{array}{l}\text { Between } \\
\text { groups }\end{array}$ & 3 & 0.046 & 0.015 & 0.926 & 0.156 \\
\hline & $\begin{array}{l}\text { Within } \\
\text { groups }\end{array}$ & 733 & 71.469 & 0.098 & & \\
\hline & Total & 736 & 71.515 & & & \\
\hline \multirow[t]{3}{*}{ WhatsApp } & $\begin{array}{c}\text { Between } \\
\text { groups }\end{array}$ & 3 & 0.012 & 0.004 & 0.957 & 0.106 \\
\hline & $\begin{array}{l}\text { Within } \\
\text { groups }\end{array}$ & 733 & 28.442 & 0.039 & & \\
\hline & Total & 736 & 28.455 & & & \\
\hline \multirow[t]{3}{*}{ Twitter } & $\begin{array}{c}\text { Between } \\
\text { groups }\end{array}$ & 3 & 0.273 & 0.091 & 0.350 & 1.097 \\
\hline & $\begin{array}{l}\text { Within } \\
\text { groups }\end{array}$ & 733 & 60.784 & 0.083 & & \\
\hline & Total & 736 & 61.057 & & & \\
\hline \multirow[t]{3}{*}{ Total } & $\begin{array}{l}\text { Between } \\
\text { groups }\end{array}$ & 3 & 0.029 & 0.010 & 0.760 & 0.390 \\
\hline & $\begin{array}{l}\text { Within } \\
\text { groups }\end{array}$ & 733 & 18.234 & 0.025 & & \\
\hline & Total & 736 & 18.263 & & & \\
\hline
\end{tabular}

\footnotetext{
*The statistical significance level is $(\mathrm{a}=0.05)$

Based on the table (10), there isn't any statistically significant difference -at the statistical significance level of $(\mathrm{a}=0.05)$ - between the impacts of the social media on improving the services of the Department which can be attributed to academic qualification. That's because the calculated $\mathrm{p}$ value is greater the statistical significance level. That means that there isn't any statistically significant difference between the respondents' attitudes in this regard which can be attributed to their academic qualification. The researcher attributes this result to the fact that social media can be used by all people regardless of their academic qualifications. He attributes this result to the fact that the posts of the Department of Lands and Survey on social media address all categories of people. Thus, one's academic qualification shall not affect the way he/she uses social media. The researcher attributes this result to the fact that all people use social media regardless of their academic qualifications.
}

\section{Recommendations}

In the light of the aforementioned results, the researcher recommends:

1- Distributing pamphlets to the service recipients of the Department of Lands and Survey in Jordan. Such pamphlets must encourage them to follow the official page of the latter department on Twitter

2- Responding faster to the inquiries of the service recipients of the Department of Lands and Survey that are sent through WhatsApp.

3- Posting more videos that provide the service recipients of the latter department with more knowledge about the measures taken for doing paper works. 
4- Raising the extent of the flexibility of the measures taken by the department. The researcher also recommends activating the role of the department in handling community responsibility. He recommends engaging the department in national projects through using Facebook

5- Posting more videos on YouTube by the department in the aim of delivering awareness-raising messages.

6- Activating the role of the complaints hotline on WhatsApp

7- Conducting further studies that address the impact of social media on improving services. Conducting similar studies that target other type of population

8- Conducting more studies that address the impact of social media on improving the services of the Department of Lands and Survey in Jordan. Conducting similar studies that target other variables

\section{References}

Al-A'raj \& Sa'd Fares (2018). Social media platforms and globalism. $1^{\text {st }}$ edition. Egypt. The Egyptian Anglo Bookshop

Al-Kurashi, Thaher \& Al-Kelani, Yasmeen (2015). The impact of social media on the process of making the purchasing decision in Amman. Al-Najah Journal for Research, 29(12), 2411-2442

Al-Madani \& Osamah Gazi (2015). The role of social media in forming public opinion among the students enrolled in Saudi universities. The Journal of Sultan Qaboos University, 3(12), 123-126.

Al-Mansour, Mohammad (2012). The impact of social media on service recipients: A comparative study targeting social media (Unpublished MA thesis). The Arab Academy in Denmark.

Al-Nsour, Hala; Aksemry, Al-Manasrah \& Al-Zyadat, Mohammad (2016). The impact of social media marketing on the purchasing intention in Jordan. The Jordanian Journal for Business Management, 12(3), 519-531.

Mustafa, Samer (2016). The impact of social media on improving the mental image among customers: A field study targeting the Syrian Telecommunication companies in Damascus. The Journal of Albaath University, 83(52), 99-145.

Qasem, Samer \& Dayoob, Jawdat (2018). The role of social media in affecting the purchasing phases: A field study targeting the Syrian Telecommunication companies. The Journal of Tishreen University for scientific studies and research. The series of the legal and economic sciences, 40(5), 327.

Reita,G (2012). Social Network Analysis: History Theory and Methodology, London: Sage Publications Ltd. ISBN.

Vansoon, M (2010). Facebook and the invasion of technological communities, New York.

\section{Copyrights}

Copyright for this article is retained by the author(s), with first publication rights granted to the journal.

This is an open-access article distributed under the terms and conditions of the Creative Commons Attribution license (http://creativecommons.org/licenses/by/4.0/). 